\title{
2
}

\section{Textbook Memories of the Cold War: Introduction to Part One}

\author{
Barbara Christophe
}

Making the case for history textbooks as valuable sources for memory practices (Christophe and Schwedes 2018), appears to be rather like charging an open door. Textbook and memory research share many assumptions and raise similar questions. Both claim that reconstructions of the past are contingent on interests and beliefs in the present; both seek to unpack the - at times rather complex - relations between times past and times present. History textbooks, which have been cogently described as 'weapons of mass instruction' (Ingrao 2009), play a vital role in sustaining mnemonic hegemonies. Selecting what counts as relevant (school) knowledge from a vast plethora of historical facts, they take part in setting the limits of what can be legitimately said (Apple 2000). Powerfully reproducing and imposing on us the categorical distinctions we tend to draw in our mediated encounters with the past, they influence what can pass for common sense.

B. Christophe $(\bowtie)$

Georg Eckert Institute for International Textbook Research, Member of the Leibniz Association, Brunswick, Germany e-mail: christophe@gei.de 
At the same time, we can distinguish between two different approaches in textbook research. Some conceive of history textbooks as the 'autobiographies of nations' (Jacobmeyer 1998), as powerful instruments for crafting a broad social consensus on how to make sense of the past. Other researchers argue that textbooks are objects of fierce struggle between competing political groups over the construction of a common-sense reality (Apple 2000). They point to the many cracks and fissures that enter textbook narratives in the course of attempts to merge different positions and to speak to different constituencies (Klerides 2010). Both camps agree, however, that history textbooks do not convey neutral knowledge, but rather participate in the construction of what Raymond Williams (1961) has called the 'selective tradition'.

Although the arguments presented so far might appear as banal truisms, they have in fact met with fierce criticism. It has been argued that textbooks are far too boring, confusing and misleading (Tyson-Bernstein 1988) to shape the minds of students. Textbook stories are said to be too predictable to be interesting, focusing exclusively on challenges successfully mastered and hardships overcome (Loewen 2007). Studies on 'textbookese' (Crismore 1984) have shown how one proposition after the other is made without rendering visible who is speaking. Researchers have criticised textbook authors for tending to speak with an anonymous but highly authoritative voice, assuming the role of 'truth giver' (Crismore 1984, 292), or a 'surveyor' (Myskow 2017) of uncontested insights. They have pointed out that the reader is ascribed the rather passive and uncomfortable position of one who is to listen but not speak back as there is nobody to argue with (Coffin 2009). Finally, scholars claim that the discursive construction of 'disinterested impartiality' (Myskow 2017, 4) and the 'appearance of neutrality' (Coffin 2009, 396) clearly comes with the risk of losing the interest of the potential reader who is known to appreciate passionate authors taking stances (Commager 1966). Although some authors (Klerides 2010; Gautschi 2010) have emphasised that textbooks have seen significant changes in recent years, especially when it comes to encouraging students to pass their own judgements, they have also noticed that there is still room for further improvement. If the chapters in this section nevertheless analyse history textbooks 
as sources for the reconstruction of memory practices, they do so because they share two core assumptions, the validity of which is not affected by the compelling critique referred to above.

Firstly, even textbooks failing to persuade their readers of the propositions they make may be effective in normalising certain distinctions, systems of categorisation, and modes of structuring a story. As tiny subtleties usually pass unnoticed and enter our minds below the radar of conscious control, they may have the greatest impact on meaning-making (Christophe 2014). We thus - literally - have to take the textbook at its word (Ott 2014). Translating these considerations into carefully designed research strategies, the contributions to this section arrive at intriguing insights.

In her analysis of current Chinese textbooks, Lisa Dyson shows how meaning-making already takes place in the table of contents. Presenting the readers with three chapters on politics, economics, and culture, each of which spans the whole of the $20^{\text {th }}$ century, the authors signal that they consider chronological turning-points in general, and the beginning and end of the Cold War in particular, less worthy of attention than the emergence of a truly multi-polar world with China as one of its dominating poles.

Teresa Oteíza and Claudia Castro point out how textbooks from Chile focus exclusively on American fears and concerns when addressing the Cuban revolution or the electoral victory of Salvador Allende. The emotions of other actors are not even mentioned; we learn nothing, for instance, about the hope felt by left-wing parties at these historic moments. As a result, the reader is powerfully instructed to empathise with the USA.

Linda Chisholm and David Fig explain how the predominant use of the passive voice in South African textbooks contributes to constructing the image of Africa and Africans as helpless victims of rival superpowers. However, they also point out that, conversely, the same textbooks completely ignore the influence of international factors on bringing down apartheid and ascribing agency exclusively to local resistance fighters.

Working on US-American textbooks, Eva Fischer also pays particular attention to micro-analysis. In one telling example she deconstructs a sentence stating that 'although' they were 'also' communist, Soviets were 
influenced by security concerns. She renders visible how the conjunction 'although' encompasses two simultaneous functions: On the one hand, it silently undermines the revisionist claim that the Soviets were fearful by implying that communists had no security concerns. On the other hand, it remains sufficiently vague about the precise relationship between being communist and having security concerns.

Focusing on current Swedish textbooks, Anders Persson describes in detail how students are instructed to judge Soviets critically and to identify with the Americans. While the former are portrayed as a faceless mass of people generally deprived of any agency, the latter are introduced as progressive and skilful individuals, as creative artists or inventive industrialists who seize any opportunity to grow.

Joanna Wojdon demonstrates how Polish textbooks always describe the USA in a favourable light, either by omitting negative aspects like the so-called witch-hunt in the McCarthy era or by focusing on solutions found to problems such as racism without examining in detail the injustices that were their root causes.

Karel Van Nieuwenhuyse elucidates how Belgian textbooks at times implicitly pass moral judgements by their choice of words. As an example he provides a close analysis of a sentence stating that the GDR was forced to become a Soviet ally while the FRG chose its attachment to the West. In addition, he unveils how textbook authors construct Western values as the natural standard by which to judge societies all over the world.

Secondly, history textbooks not only tell us which historical interpretations enjoy dominance; in various ways they also provide us with insights into controversies. At times, ambivalence or non-coherence in texts points to what critical educationalist Michael Apple has called the 'politics of incorporation' (Apple 2000), which aims at stabilising hegemony by simultaneously giving space to and taming the voices of formerly excluded minorities. Elsewhere, vagueness caters to the need to avoid open conflict over unresolved issues of the past. Finally, in some cases significant discrepancies between textbooks published by different publishing houses remind us of unresolved societal disputes. The chapters in this section provide illustrative examples of all three variants. 
Eva Fischer provides a detailed analysis of how American textbooks include revisionist approaches towards the Cold War by admitting, for example, that the USA pursued rather egoistic goals with its Marshall Plan. At the same time she points out that only watered-down versions of these arguments are incorporated in order to ensure that they would not destabilise the traditional positive self-image.

Writing on Russian textbooks, Alexander Khodnev reveals that their portrayals of the Cold War remain somewhat disparate. The four most widely used textbooks differ significantly, not only with regard to how much space they allocate to the so-called Third World or to cultural aspects; even when it comes to core issues such as the blame for the conflict we see a broad range of different positions. While some authors admit that there is no clear-cut answer to this question, others blame the iron fist brandished by the Americans at all opponents to their hegemonic plans.

Anders Persson points to significant differences in the portrayals of the USA offered by different Swedish textbooks. While most books describe the Western superpower in rather traditional terms as the epitome of freedom and success, as a country to which people migrated in pursuit of happiness, one mentions how women, the poor, slaves and natives were disenfranchised and how the Civil War between North and South claimed more victims than all other wars in which the USA has participated.

Karel van Nieuwenhuyse shows that Belgian textbooks differ with regard to the homogeneity they ascribe to the Eastern bloc. While some authors dedicate space to counter-voices only from within the Western camp, others focus on dissent in the Eastern camp as well.

Joanna Wojdon identifies tensions in portrayals of Winston Churchill in Polish textbooks. While Churchill is described as the first Western politician to notice the aggressiveness of the Soviet Union, he is also introduced as an outspoken critic of the transfer of German territories to Poland. However, as Wojdon argues, in the eyes of Polish textbook authors, Poland gained more from the end of cooperation between the Western powers and the USSR than it suffered from the same Western powers striking an alliance with the former war enemy Germany.

Markus Furrer reconstructs four powerful and potentially contradictory images that dominate Swiss textbook narratives of the Cold War. Switzerland is portrayed (i) as overwhelmed by anti-communist hysteria, 
(ii) as a potential victim of a nuclear war, (iii) as a social space in which the economy boomed and a democratic consociation took firm root, and (iv) as a society that suffered from the iron curtain.

Finally, textbooks lend themselves particularly well to international comparison. With the global expansion of the nation-state and the school as one of its core institutions, textbooks have literally travelled the world (Christophe 2014), performing more-or-less the same instructional functions across spaces and places. The contributions to this section offer intriguing and at times surprising findings on similarities as well as differences between textbook narratives of the Cold War.

Whereas post-apartheid textbooks in South Africa seem to constitute the exception, portraying the USSR in a more favourable light, Chinese and Chilean textbook authors appear to agree on the insignificance of the Soviet Union, which is given only scant attention and moreover characterised as a failing, and thus negligible, state and social system. In fact, Chinese textbooks, like some Russian and the majority of Polish textbooks, do not give much priority to the Cold War at all. Snippets of information on the conflict are scattered over several chapters, all of which span the whole period from 1945 to the present day under shifting titles.

US-American and Russian textbooks resemble each other in one structural aspect. Both are ready to retract part of the blame they formerly placed on the 'other', the ideological rival during the Cold War, but stop short of criticising the national 'self'. Russian textbooks avoid the term 'occupation', for instance, when they deal with Cold War relations between the USSR and Eastern Europe, and US textbooks never mention capitalism as being behind the American interest in penetrating European markets with the help of the Marshall Plan.

With regard to the attribution of agency, textbooks from Poland and Sweden share one crucial aspect. Both feature active citizens only when writing about the extended West; in the extended East only politicians, primarily great white men, are presented as capable of having agency.

To sum up, the contributions to this section offer us intriguing insights into textbook discourses on the Cold War in different societies and, at the same time, present us with innovative methodological suggestions on how to analyse textbooks as manifestations of situated memory practices. 


\section{References}

Apple, Michael. 2000. Official Knowledge: Democratic Education in a Conservative Age. New York: Routledge.

Christophe, Barbara. 2014. Kulturwissenschaftliche Schulbuchforschung: Trends, Ergebnisse, Potentiale. Eckert. Working Papers 6.

Christophe, Barbara and Kerstin Schwedes. 2018. 'Between Persistent Differences and Vagueness: Textbook Narratives about the First World War'. In The Long End of the First World War, edited by Katrin Bromber, Katharina Lange, Heike Liebau and Anorthe Wetzel, 209-234. Frankfurt a. M.: Campus.

Coffin, Caroline. 2009. Historical Discourse. The Language of Time, Cause and Evaluation. London: Continuum.

Commager, H. 1966. The Nature and Study of History. Columbus, Ohio: Charles E. Merrill.

Crismore, Avon. 1984. 'The Rhetoric of Textbooks: Metadiscourse'. Journal of Curriculum Studies 16, no. 3: 279-296.

Gautschi, Peter. 2010. Anforderungen an heutige und künftige Schulgeschichtsbücher. Beiträge zur Lehrerinnen- und Lehrerbildung 28: $125-137$.

Ingrao, Charles. 2009. 'Weapons of Mass Instruction: Schoolbook and Democratisation in Multiethnic Central Europe'. Journal of Educational Media, Memory, and Society 1, no. 1: 180-189.

Jacobmeyer, Wolfgang. 1998. 'Das Schulgeschichtsbuch - Gedächtnis der Gesellschaft oder Autobiographie der Nation?' Geschichte, Politik und ihre Didaktik 26: 26-35.

Klerides, Eleftherios. 2010. 'Imagining the Textbook: Textbooks as Discourse and Genre'. Journal of Educational Media, Memory, and Society 2, no. 1:31-54. Loewen, James. 2007. Lies my Teacher Told Me: Everything your American History Textbook Got Wrong. New York: New press.

Myskow, Gordon. 2017. 'Surveying the Historical Landscape: The Evaluative Voice of the Textbook'. Functional Linguistics 4, no. 7: 1-15.

Ott, Christine. 2014. 'Das Schulbuch beim Wort nehmen. Linguistische Methodik in der Schulbuchforschung. In Methodologie und Methoden der Schulbuch-und Lehrmittelforschung, edited by Petr Knecht, Eva Mattes, Sylvia Schütze and Bente Aamotsbakken, 254-263. Bad Heilbrunn: Klinkhardt. Tyson-Bernstein, Harriet. 1988. A Conspiracy of Good Intentions: America's Textbook Fiasco. Washington: Council for Basic Education.

Williams, Raymond. 1961. The Long Revolution. London: Chatto and Windus. 
Open Access This chapter is licensed under the terms of the Creative Commons Attribution 4.0 International License (http://creativecommons.org/licenses/ by/4.0/), which permits use, sharing, adaptation, distribution and reproduction in any medium or format, as long as you give appropriate credit to the original author(s) and the source, provide a link to the Creative Commons licence and indicate if changes were made.

The images or other third party material in this chapter are included in the chapter's Creative Commons licence, unless indicated otherwise in a credit line to the material. If material is not included in the chapter's Creative Commons licence and your intended use is not permitted by statutory regulation or exceeds the permitted use, you will need to obtain permission directly from the copyright holder.

(c) (i) 